\title{
Gry komputerowe jako hiperteksty
}

\section{Streszczenie}

Artykuł prezentuje mediolingwistyczną analizę gier komputerowych, która w sposób szczególny skoncentrowała się na kategorii hipertekstualności. Korpus badawczy stanowią gry komputerowe różnego rodzaju, aby jak najlepiej przedstawić ich medialnie uwarunkowaną heterogeniczność. Udzielona zostanie odpowiedź na pytanie, czy spełniają one kryteria hipertekstualności i, jeśli tak, czy jest to hipertekstualność pełna, czy też częściowa, tj. czy gra komputerowa stanowi jeden hipertekst jako całość, czy też jest ona tworem złożonym z jednego lub wielu hipertekstów i ewentualnych innych elementów. W ramach analizy zostanie również zweryfikowane, czy gry komputerowe wykazują cechy specyficzne, wyróżniające je na tle najbardziej popularnej formy hipertekstu, czyli tekstów będących częścią WWW.

Słowa kluczowe: medialność, hipertekst, gra komputerowa, tekstualność

\section{Wstęp}

Gry towarzyszą człowiekowi prawie od zarania dziejów. Kojarzone dzisiaj przede wszystkim z rozrywką, są od wieków jednym ze sposobów spędzania wolnego czasu. Należy jednak podkreślić, że spełniają one również funkcję kulturotwórczą oraz edukacyjną. Można nawet przypuszczać, że istniały jeszcze przed jakąkolwiek kulturą, są bowiem także zjawiskiem, które można zaobserwować wśród zwierząt. Uogólniając, można przyjąć, że pierwszymi grami w węższym tego słowa znaczeniu, które stanowiły nierozłączną część człowieczeństwa, były różnego rodzaju wydarzenia sportowe (Miejsce gier w kulturze i społeczeństwie, 2012). Gry od początku cywilizacji po dziś dzień napędzają zmiany kulturowe, ponadto same w sobie zmieniają się, ewoluują wraz z rozwojem kultury. 
W erze Nowych Mediów nie mogło zatem zabraknąć ich cyfrowego przedstawiciela, jakim są gry komputerowe.

Gry komputerowe powstały już dość dawno, bowiem w latach pięćdziesiątych XX wieku (Charles i in., 2007: 2; Walz, 2010: 2), były wtedy jednak głównie elementem środowiska informatyków. Dla szerszego grona odbiorców stały się dostępne stosunkowo późno (por. Ackermann, 2011: 62). Z tego powodu nadal są uznawane za dość nowe i, co trzeba zaznaczyć, wciąż dynamicznie rozwijające się zjawisko. Mimo iż są one elementem badań wielu dziedzin naukowych - jako najważniejsze należy wymienić na przykład ludologię czy medioznawstwo - relatywnie rzadko stanowią obiekt analizy językoznawczej, w szczególności w zakresie lingwistyki tekstu oraz mediów. Przyczyną są przede wszystkim trudności natury metodologicznej (por. Stertkamp, 2017: 7).

Celem niniejszego artykułu jest przedstawienie mediolingwistycznej analizy gier komputerowych, która ma na celu udzielenie odpowiedzi na pytanie, czy mają one strukturę hipertekstu i, jeśli tak, w jakim stopniu wykazują one parametry hipertekstualności oraz czy posiadają cechy specyficzne, odróżniające je od tradycyjnego przykładu hipertekstu, czyli stron internetowych w sieci WWW.

\section{Pojęcie gry komputerowej}

Przed rozpoczęciem analizy należy jednak wyjaśnić znaczenie samego obiektu badań, jakim są gry komputerowe. Podobnie jak w wielu innych przypadkach również pojęcie gra komputerowa jest dość wieloznaczne i wymaga sprecyzowania. Za punkt wyjścia można uznać zdefiniowanie szerszego, nadrzędnego pojęcia, jakim jest gra. Gry, jako forma rozrywki, za każdym razem wykazują trzy cechy specyficzne. Po pierwsze, posiadają one pewnego rodzaju zbiór obiektów i działań ściśle z daną grą powiązanych. Może to być na przykład rzut kostką lub struktura gry planszowej oraz przede wszystkim jej reguły. Kolejną cechą jest sens gry, czyli jej funkcja. Obok innych funkcji (takich jak dydaktyka) najważniejszą jest rozrywka. Jako ostatnie kryterium może zostać nazwany cel gry, czyli przykładowo sukces gracza (por. Jacko, 2016: 68).

Znając już wyżej wymienione cechy podstawowe i zarazem obligatoryjne gier w szerokim znaczeniu, można przejść do definiowania węższego, lecz pokrewnego pojęcia, jakim jest gra wideo. Jak sama nazwa wskazuje, jest to rodzaj gry bazujący na ruchomym obrazie. Gry wideo są zatem zawsze medialnie związane z konkretnym medium technologicznym ${ }^{1}$ - ekranem, który umożliwia ich odtwarzanie, a co za tym idzie - recepcję. Dodatkowo, bardzo istotną cechą gier wideo jest fakt, że przedstawiają one zawsze jakąś akcję w formie generowanych komputerowo animowanych obrazów (por. Fritz, 1988: 70). Osoba grająca pozostaje $\mathrm{w}$ interakcji z przedstawianymi na ekranie wydarzeniami, przez co determinuje przebieg gry. Należy także zaznaczyć, że oprócz animacji w grę wideo mogą

${ }^{1}$ Roland Posner (1986: 294) rozumie media technologiczne jako techniczne środki produkcji znaków, które umożliwiają połączenie między nadawcą a odbiorcą. 
być wbudowane inne elementy, na przykład filmy lub elementy z obrazem statycznym. Gra wideo jest zatem obiektem multi- oraz częściowo intermedialnym.

Pojęciem podobnym do gier wideo są gry komputerowe, które jednak mogą być rozumiane co najmniej dwojako. Kluczową cechą gier komputerowych jest fakt, że są one odtwarzane na urządzeniach komputerowych. Należy zaznaczyć, że mogą być one jednocześnie grami wideo, gdy na przykład ich akcja przedstawiana jest na ekranie za pomocą komputera. Dotyczy to raczej większości przypadków gier komputerowych, należy jednak podkreślić, że pojęcie to delikatnie wykracza poza obręb gier wideo, gdyż obejmuje również gry komputerowe bez ekranu, takie jak skomputeryzowane gry planszowe (por. Fritz, 1988: 70). W dzisiejszych czasach dzięki rozwojowi techniki, ale również dzięki temu, że technika komputerowa rozprzestrzeniła się w codziennych sferach życia, zmieniło się postrzeganie pojęcia komputer, które często bywa jednoznaczne z tak zwanym PC, co z języka angielskiego oznacza personal computer, czyli komputer osobisty - mały, wydajny komputer, który służy na przykład do pracy, rozrywki itp. Prowadzi to do tego, że pojęcie gra komputerowa może być w węższym znaczeniu rozumiane nie jako gra wideo odtwarzana na urządzeniu komputerowym w ogóle, lecz jako gra wideo odtwarzana na komputerze osobistym, czyli tak zwana gra PC. Pojęcie to nie obejmowałoby wtedy natomiast gier wideo odtwarzanych na innych urządzeniach komputerowych, na przykład konsolach do gier (Xbox, PlayStation itp.). Najprościej różnicę tę da się przedstawić graficznie (rys. 1).

\section{Gry}

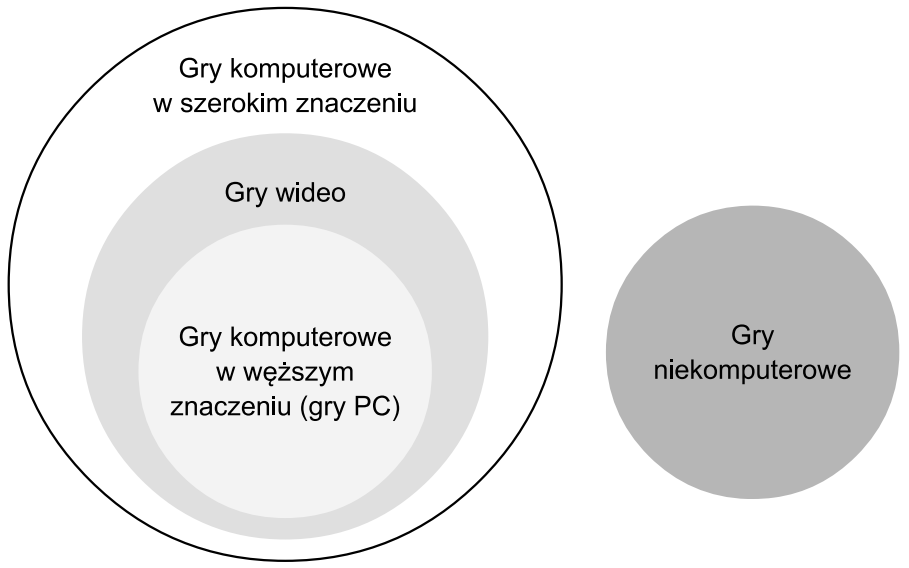

Rysunek 1. Rozróżnienie znaczeń gier i gier komputerowych Źródło: opracowanie własne.

Dalsza mediolingwistyczna analiza będzie dotyczyć gier komputerowych w węższym znaczeniu, gry wideo odtwarzane na innych komputerowych urządzeniach niż PC nie będą w niej zatem brane pod uwagę. Pojęcia gry komputerowe i gry PC będą dalej uznawane za synonimy i stosowane zamiennie. 


\section{Hipertekst i jego obligatoryjne cechy}

Przed przystąpieniem do analizy należy sprecyzować, co rozumiane jest pod pojęciem hipertekst. Jak sama nazwa wskazuje, jest to przede wszystkim pewien rodzaj tekstu. Nie należy jednak w tym przypadku ograniczać się do typowo lingwistycznych kryteriów tekstualności, gdyż hiperteksty bardzo często wybiegają poza sferę językową. Uzasadnione będzie zatem odwołanie się do semiotycznej definicji tak zwanych tekstów kultury. Są to artefakty, czyli produkty zamierzonych działań człowieka, które ponadto zawsze posiadają jakieś uwarunkowane kulturowo funkcje, są zatem zarazem instrumentami. Dodatkowo należy podkreślić, że muszą być one kodowane. Oznacza to, że w danej kulturze musi istnieć kod, który przypisuje tekstowi kultury konkretne elementy znaczone (por. Posner, 1991: 46). Przedrostek hiper wskazuje natomiast na wyjątkowość hipertekstów, na wyższy poziom w porównaniu z tradycyjnymi tekstami. Nasuwa się zatem pytanie, co odróżnia hiperteksty od innych, tradycyjnych tekstów. Do odpowiedzi przybliżyć może odwołanie się do dwóch ważnych kryteriów - nielinearności oraz oparcia na urządzeniach komputerowych ${ }^{2}$.

Jedną z ważniejszych cech hipertekstów jest wspomniana nielinearność. W tradycyjnych tekstach kolejność czytania jest z zasady ustalona przez producenta tekstu, odpowiada zatem na przykład kolejności stron, z pominięciem oczywiście faktu, że odbiorca może sprzeciwić się tej kolejności (por. Huber, 2003: 35). W przypadku hipertekstów o kolejności działań recepcyjnych rozstrzyga natomiast wyłącznie odbiorca, który decyduje, w zależności od zainteresowań, które moduły chce przejrzeć, a które pominąć. Hipertekstom przypisywana jest zatem możliwość selektywnej lektury (por. Storrer, 2008: 319). Często w odniesieniu do czytania hipertekstów używa się, ze względu na ich nielinearny charakter, określenia nawigacja czy też browsing (por. Huber, 2003: 35).

Nasuwa się jednak pytanie, co umożliwia stworzenie nielinearnej struktury hipertekstu. Kluczowym pojęciem w szukaniu odpowiedzi na to pytanie jest kategoria cyfrowości. Hiperteksty są tworzone i odtwarzane na urządzeniach skomputeryzowanych, jest to zatem ich druga cecha obligatoryjna (por. Storrer, 2008: 319). Oczywiście powstają również inne nielinearne, tradycyjne teksty, oparte na mediach drukowanych. Jako przykłady można podać różnego rodzaju czasopisma oparte na designie, który dzieli ich tekst na wiele nielinearnie zorganizowanych modułów (por. Storrer, 2008: 319). Biorąc jednak pod uwagę główną ideę hipertekstualności czy też główną funkcję, która została przypisana hipertekstom i pojawiła się już jako ich kluczowa cecha przy pierwszych konceptach czyli przede wszystkim łatwość i szybkość odszukiwania informacji (por. Nelson, 1965), można uznać, że wspomniane teksty drukowane nie powinny być nazywane hipertekstami, gdyż brakuje w nich umożliwionej przez komputeryzację automatyzacji (por. Schmitz, 2015: 94). Urządzenia komputerowe pozwalają na produkcję i recepcję hipertekstów, są zarazem elementem obowiązkowym, ponieważ umożliwiają automatyczne i przede

${ }^{2}$ Kryteria te są uznawane przez wielu badaczy za obligatoryjne i pojawiły się już przy początkowych definicjach hipertekstowości (na przykład Nelson, 1965). 
wszystkim bezpośrednie przejścia między modułami ich nielinearnej struktury. Hiperteksty są bowiem strukturą tekstową, która nie może być wydrukowana (por. Nelson, 1972: 253).

Również sama struktura hipertekstu, wspierana przez komputeryzację, umożliwia jego nielinearną recepcję. Hiperteksty składają się zasadniczo z dwóch rodzajów elementów. Jednym z nich są tak zwane węzły. W przypadku sieci WWW są one najczęściej potocznie określane mianem stron. W pewnym stopniu przypominają tradycyjne teksty drukowane, mają bowiem podobną formę, strukturę czy też layout (por. Huber, 2003: 24). Wydrukowana wersja węzłów teoretycznie nie powinna różnić się pod względem budowy od wersji elektronicznej. W praktyce, zwracając uwagę na to, że istnieją większe rodzaje węzłów, można jednak dostrzec znaczące różnice. Węzły wyświetlane na ekranie nie mają bowiem z góry narzuconych granic. Każdy węzeł może zawierać nieograniczoną ilość znaków, a nawigację w obrębie jednego węzła umożliwia tak zwany scrolling (Huber, 2003: 27). Jeden elektroniczny węzeł wyświetlany na ekranie może zatem odpowiadać obszarowi wielu wydrukowanych stron tekstu. Węzły same w sobie są jednak mniej lub bardziej linearne i przypominają wspomniane wcześniej strony czasopism. Aspekt nielinearności wprowadza natomiast drugi bardzo istotny element, jakim są łącza, zwane również linkami. Są one pewnego rodzaju elektronicznymi odsyłaczami, które pozwalają na błyskawiczne, w pełni automatyczne i bezpośrednie przejścia (na przykład poprzez kliknięcie lub dotknięcie palcem ekranu) do innych węzłów lub, rzadziej, do elementów w obrębie jednego węzła (Huber, 2003: 25). W drugim przypadku pełnią one częściowo funkcję zastępczą dla scrollingu i jeszcze bardziej przyspieszają nawigację. Linki mogą ponadto również odsyłać do węzłów należących do innych hipertekstów.

Podsumowując, hiperteksty muszą spełniać dwa ważne kryteria, jakimi są nielinearność oraz oparcie na urządzeniach komputerowych. Trzeba też zaznaczyć, że nie wszystkie teksty cyfrowe są hipertekstami. Istnieją bowiem także tak zwane e-teksty, czyli teksty wyświetlane na ekranie dzięki komputerom, niespełniające jednak kryterium nielinearności. Są to na przykład elektroniczne publikacje książkowe bazujące na budowie składającej się z węzłów i linków (por. Huber, 2003: 22).

\section{Fakultatywne kryteria hipertekstualności}

Poza obowiązkowymi kryteriami, które muszą być spełnione, aby można było mówić o hipertekście, występuje kilka cech dodatkowych, fakultatywnych, które są jednak równie istotne i na które należy zwrócić uwagę w późniejszej analizie gier komputerowych.

Jedna z nich to multikodalność. Jak już wspomniano, hiperteksty nie muszą być wyłącznie językowymi tworami. W większości przypadków są one pewnego rodzaju mieszanką różnych obiektów, systemów znaków. Może to być na przykład język z wideo, dźwiękiem, obrazem statycznym itp. (por. Storrer, 2008: 321). Multikodalność pozostaje jednak mimo wszystko cechą nieobligatoryjną, gdyż, choć występuje bardzo często, do zaobserwowania są różne wyjątki, takie jak niektóre strony Wikipedii, na których występują wyłącznie elementy językowe. 
Kolejną ważną, ale jednak fakultatywną cechą, jest dynamika hipertekstów. Pojęcie to oznacza, że nie są one w wielu przypadkach jednostkami statycznymi i podlegają częstym aktualizacjom (Storrer, 2008: 321). Zmiany w treści hipertekstu mogą być wprowadzane w dowolnych odstępach czasowych. Niektóre ich elementy są usuwane, inne rozszerzone, zmodyfikowane, bardzo często są też dodawane zupełnie nowe komponenty. Najlepszym przykładem są różnego rodzaju portale informacyjne w sieci WWW. Dynamika odróżnia je od tradycyjnych tekstów drukowanych - mogą być uzupełniane w bardzo krótkim czasie. W szerokim znaczeniu dynamiczności bardzo trudno jest podać jakąś hipertekstualną stronę WWW, która nie spełniałaby tego kryterium, gdyż każda z nich jest w różnych interwałach czasowych odświeżana na przykład poprzez zmianę layoutu. Ze względu na obecność hipertekstów o charakterze archiwizacyjnym, cecha ta pozostaje jednak fakultatywna.

Jako następne kryterium może zostać uznana interakcja. Oznacza ona różnego rodzaju metaforyczne relacje między komputerem a człowiekiem i związane z nimi reakcje. Najprostszą z nich może być zwykła aktywacja hiperłącza. Pod pojęciem interakcji rozumiane są tutaj jednak bardziej złożone interaktywne działania, takie jak używanie wyszukiwarek, proces zoomingu oraz komunikacja z różnego rodzaju botami, na przykład wirtualnymi doradcami (Storrer, 2008: 322).

Ostatnią ważną cechą jest wspieranie komunikacji. Nie chodzi tu jednak o wspomnianą metaforyczną interakcję między sprzętem a użytkownikiem, lecz o rozmowy między użytkownikami hipertekstu, które mogą wykazywać różny stopień synchroniczności. Jako przykład można podać synchroniczne rozmowy głosowe, quasi-synchroniczne dialogi na czacie oraz asynchroniczne dyskusje na forach internetowych lub komunikację poprzez e-mail (Storrer, 2008: 322).

\section{Gra komputerowa jako hipertekst}

Przechodząc do analizy gier, należy przede wszystkim zwrócić uwagę na stopień realizacji cech hipertekstualności. Wychodząc z samej definicji gier komputerowych, można stwierdzić, że spełniają one pierwsze obligatoryjne kryterium, jakim jest oparcie na urządzeniu komputerowym. Gry PC odtwarzane są na komputerze osobistym oraz wyświetlane na ekranie, nie podlega więc wątpliwości, że istnieje możliwość ich automatyzacji. Rozstrzygającą cechą zostaje zatem nielinearność, która umożliwi stwierdzenie, czy w przypadku gier PC mamy do czynienia z hipertekstami, czy e-tekstami. Aby odpowiedzieć na to pytanie, należy przeanalizować strukturę gier, ich węzły oraz relacje między nimi. Najprościej da się to zobrazować graficznie (rys. 2). 


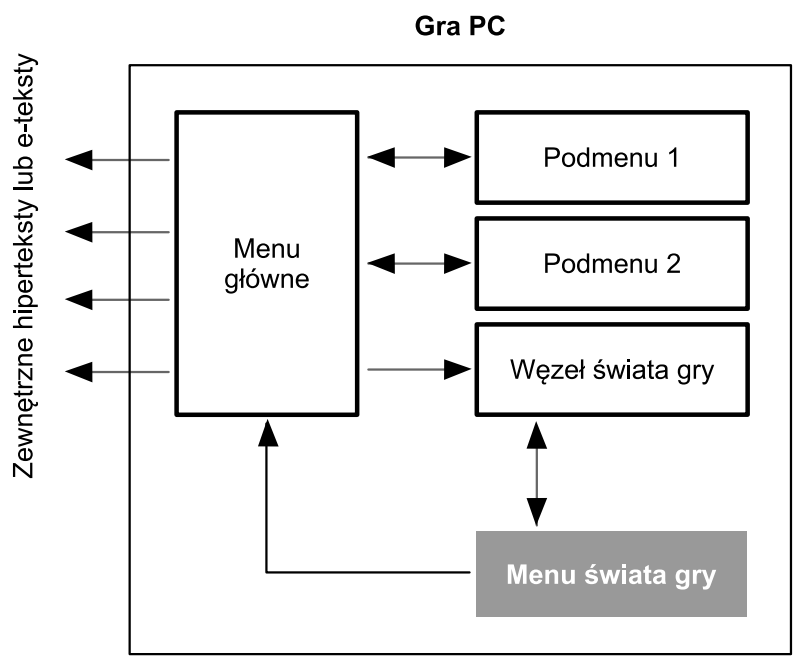

Rysunek 2. Przykładowa struktura hipertekstualnych gier komputerowych Źródło: opracowanie własne.

Każda gra komputerowa zbudowana jest zasadniczo z tak zwanego menu głównego. Jest to pewnego rodzaju panel kontrolny, węzeł główny zbudowany z różnego rodzaju linków prowadzących do innych węzłów, między innymi do różnych rodzajów podmenu na przykład z ustawieniami parametrów graficznych, informacjami o grze itp., ale także do węzła świata gry ${ }^{3}$, który zostanie opisany dalej. Ponadto istnieje możliwość występowania linków odsyłających do innych, zewnętrznych hipertekstów, przeważnie do sieci WWW, lub zewnętrznych e-tekstów, na przykład instrukcji do gry. Warto jednak zaznaczyć, że jest to zjawisko znajdujące się głównie w grach online ${ }^{4}$. W grach PC istnieje również menu świata gry, które dostępne jest wyłącznie z węzła świata gry. Wyposażone jest ono w linki podobne do menu głównego - odsyła do podmenu na przykład z ustawieniami gry, umożliwia zachowanie stanu rozgrywki, ale przede wszystkim pozwala na powrót do menu głównego. Jak łatwo zauważyć, struktura menu jest zdecydowanie nielinearna. Kolejność recepcji ustalana jest wyłącznie przez gracza z pominięciem oczywiście ograniczeń strukturalnych narzucanych przez producenta. Węzły menu głównego są zbudowane przeważnie z elementów werbalnych, obiekty graficzne używane są raczej w formie tła i bardzo często nie wpływają znacząco na odbiór tekstu (nie przekazują kluczowych informacji).

${ }^{3}$ Pod określeniem świat gry rozumiana jest wirtualna przestrzeń przedstawiana graczowi (odbiorcy) podczas rozgrywki właściwej.

${ }^{4}$ Typologizacja gier komputerowych jest dość problematyczna (por. Klimmt, 2001: 482). Jako gry online można jednak określić produkcje, do których wymagane jest połączenie internetowe. Przeciwieństwem gier online byłyby wtedy gry offline. 


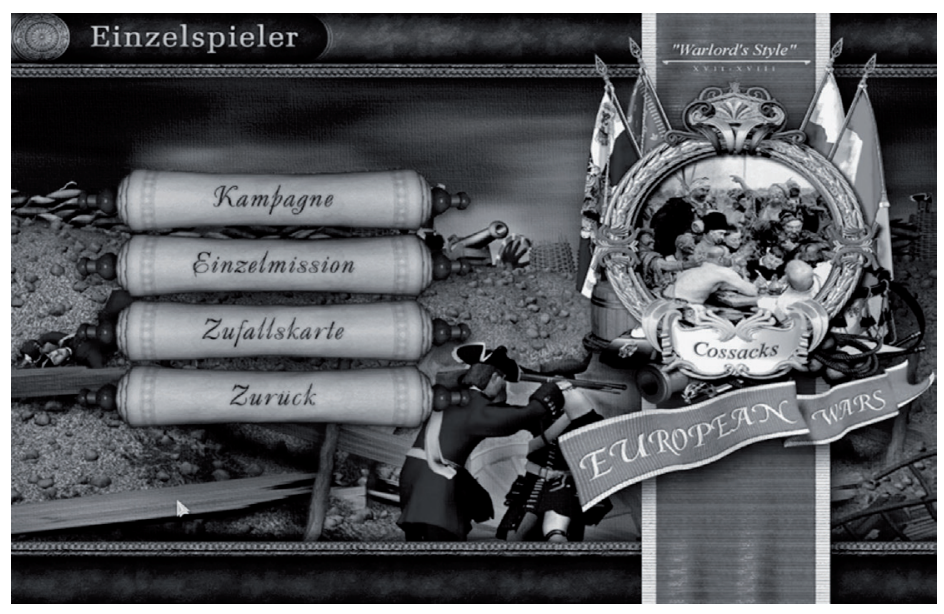

Rysunek 3. Podmenu w grze offline Kozacy: Europejskie boje. Z lewej strony widoczne są linki do węzłów wprowadzających do świata gry oraz łącze powrotne do menu głównego. U góry nazwa węzła ułatwiająca nawigację, po prawej tytuł gry. Wszystko znajduje się na tle w formie obrazu statycznego, które pełni funkcję zdobniczą

Źródło: opracowanie własne.

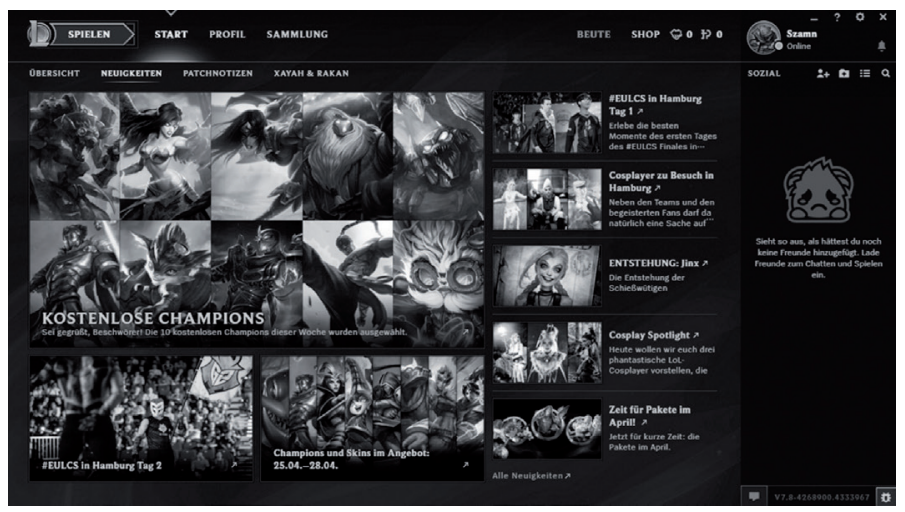

Rysunek 4. Menu główne w grze online League of Legends. U góry widoczne linki do podmenu oraz do węzła świata. W centralnej części charakterystyczne dla gier online linki do zewnętrznych hipertekstów, w tym przypadku do sieci WWW. Po prawej lista znajomych oraz link do czatu, które znajdują zastosowanie wyłącznie w grach online Źródło: opracowanie własne.

Bardzo interesującym elementem jest wspomniany węzeł świata gry. Poza linkiem do menu świata gry zawiera on w sobie różnego rodzaju interaktywne elementy. Należą do nich przykładowo wirtualne przedmioty lub postacie. Większość z nich może być aktywowana na przykład poprzez kliknięcie i odsyła do podwęzłów świata gry, są one zatem pewnego rodzaju linkami. Węzłami docelowymi tych linków mogą być różnego rodzaju okna z dialogami, opisy zadań, które gracz musi wykonać, sceny w formie animowanego 
wideo itp. Ponadto mogą one zawierać dodatkowe linki odsyłające do coraz to niższych węzłów. Wszystkie z nich są w mniejszym lub większym stopniu semantycznie powiązane z węzłem głównym świata gry. Hiperłącza świata gry zasadniczo nie narzucają żadnych ograniczeń dotyczących kolejności ich aktywowania. Węzeł świata gry i jego podwęzły są zatem zorganizowane nielinearnie. Oczywiście stopień tej nielinearności zależy od rodzaju gry PC. Najbardziej nielinearne wydają się tak zwane RPG, czyli gry, w których gracz wciela się w rolę bohatera z dość rozbudowanej historii, rozwija go i wykonuje różnego rodzaju zadania bazujące w dużej mierze na wirtualnej komunikacji z innymi, sterowanymi komputerowo postaciami.

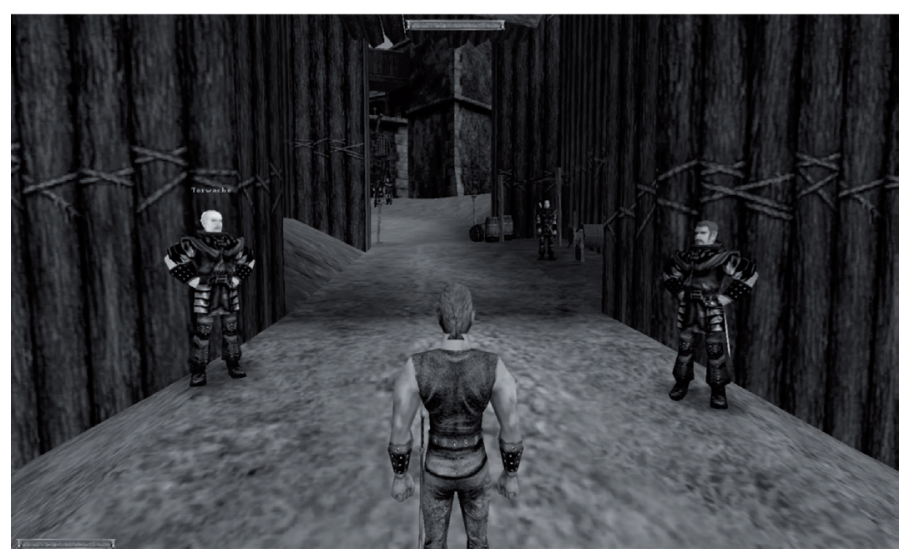

Rysunek 5. Trójwymiarowy węzeł świata gry w grze Gothic. W centrum znajduje się postać sterowana przez gracza, która umożliwia nawigację w hipertekście. Po prawej oraz lewej stoją dwie postacie sterowane przez komputer (NPC), pełniące funkcję linków, których aktywacja prowadzi do wyświetlenia podwęzłów - w tym przypadku okien dialogu Źródło: opracowanie własne.

Gry PC spełniają dwa obligatoryjne kryteria, mogą być zatem postrzegane jako hiperteksty z ewentualnymi linearnymi podelementami e-tekstualnymi ${ }^{5}$.

\section{Gry komputerowe a cechy fakultatywne hipertekstu}

Warto zwrócić uwagę na cechy fakultatywne hipertekstów w odniesieniu do gier komputerowych.

Nie ulega wątpliwości, że wszystkie nowoczesne gry PC są multikodalne. Bazują one na obrazie, który wizualizuje wirtualny świat gry i wpływa na decyzje podejmowane przez gracza. Bardzo ważne są jednak elementy werbalne, zarówno pisane, jak i mówione, gdyż to one przedstawiają fabułę, reguły oraz cel gry. W przeciwieństwie do WWW,

${ }^{5}$ Do elementów e-tekstualnych świata gry można zaliczyć na przykład linearnie zorganizowane wirtualne książki, których węzły połączone są linkami. 
gdzie zdarzają się jeszcze hiperteksty o charakterze wyłącznie językowym, gra PC bez obrazu nie jest w stanie istnieć. Multikodalność, będąca cechą fakultatywną hipertekstów w ogóle, staje się zatem kryterium obowiązkowym przy definiowaniu hipertekstualności gry komputerowej.

Kolejnym ważnym kryterium jest dynamika. Należy wyjść z założenia, że wszelkie aktualizacje software'u gry wpływają na zmiany w sferze tekstualności czy też hipertekstualności, czyli każda aktualizacja gry jest oznaką jej dynamiki. W etapie produkcji gry dynamika jest zdecydowanie największa, zmniejsza się w momencie wydania gry komputerowej, a następnie stopniowo zanika aż do etapu dynamiki zerowej, kiedy to gra nie podlega już żadnym aktualizacjom. Warto jednak zaznaczyć, że okres dynamiki zerowej dotyczy z zasady jedynie gier offline, wejście gry online w ten etap wiąże się natomiast zasadniczo z jej ,śmiercią”. Można zatem stwierdzić, że gry komputerowe są W znacznym stopniu dynamicznymi hipertekstami. Poziom dynamiki spada jednak wraz z czasem upływającym od momentu wydania. W przypadku wielu gier online dynamika staje się natomiast kryterium obowiązkowym.

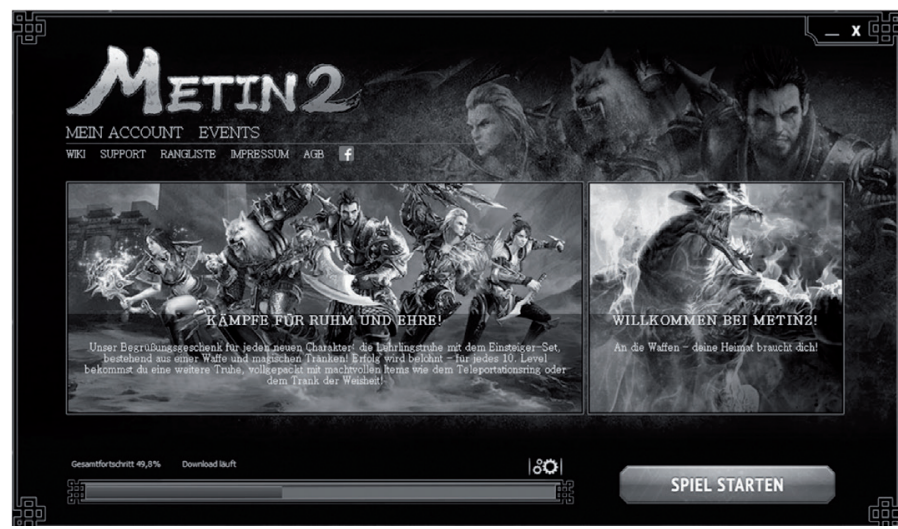

Rysunek 6. Przykład dynamiki w grze online Metin 2. Na dole widoczny pasek postępu aktualizacji treści gry

Źródło: opracowanie własne.

Kolejnym fakultatywnym kryterium szeroko pojętych hipertekstów jest interakcja. W przypadku gier komputerowych staje się ona jednak zdecydowanie cechą obligatoryjną. Najlepszym przykładem interakcji w obrębie gier PC są wirtualne dialogi między sterowanym przez gracza bohaterem a NPC, czyli postaciami sterowanymi przez komputer. 


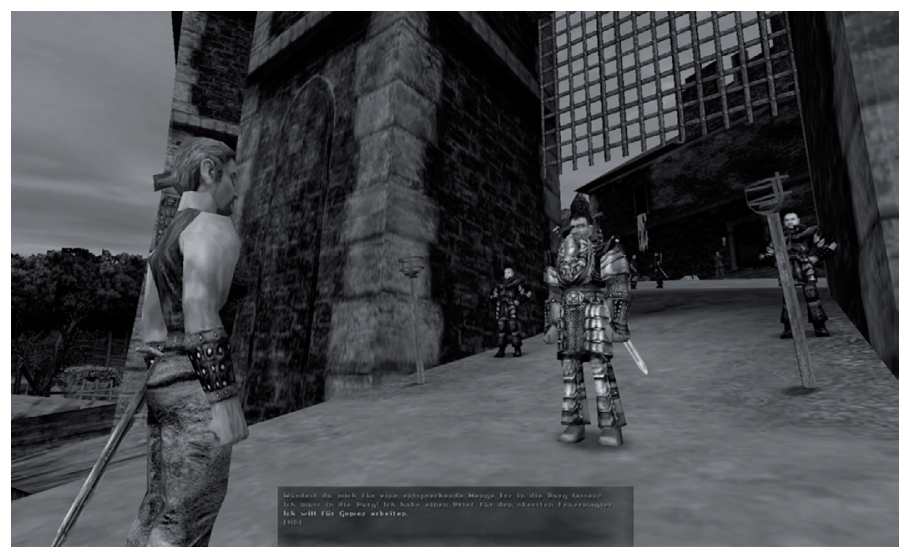

Rysunek 7. Przykład interakcji w grze Gothic - wirtualny dialog z postacią sterowaną przez komputer. Na dole widoczne linki prowadzące do węzłów przedstawiających wypowiedzi postaci, będące zatem pewnego rodzaju symulacją rozmowy

Źródło: opracowanie własne.

Jako ostatnie kryterium przedstawione zostało ułatwianie komunikacji. Gry komputerowe online mają zasadniczo wbudowane narzędzia do komunikacji. Przeważnie są to okna czatu, umożliwiające quasi-synchroniczną komunikację między graczami. Jest to element bardzo istotny, gdyż w znaczącym stopniu ułatwia rozgrywkę i recepcję. W wielu grach online występuje ponadto nie jeden, lecz wiele rodzajów czatu. Niektóre tytuły wyposażone są nawet w tak zwany czat głosowy. Można zatem wnioskować, że ostatnie kryterium staje się cechą obligatoryjną w przypadku gier online. Gry offline są natomiast pozbawione wbudowanych komunikatorów.

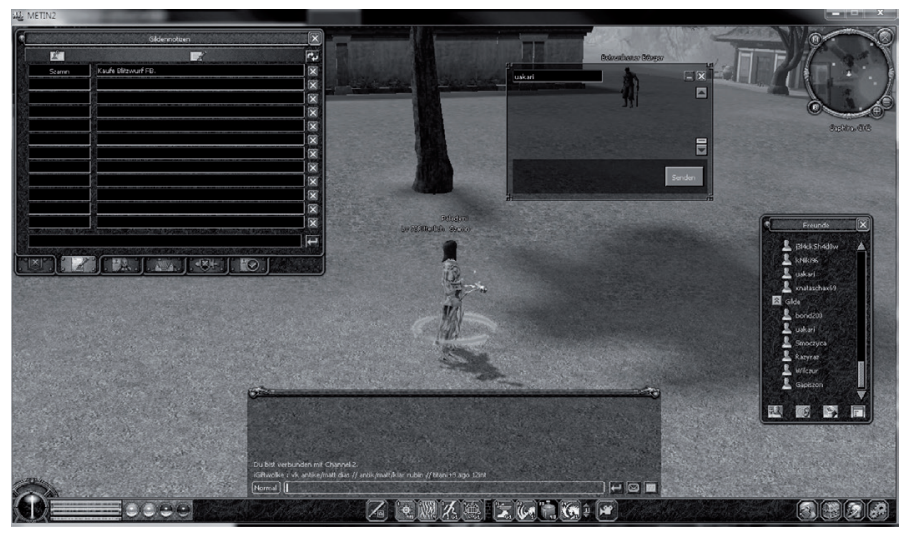

Rysunek 8. Wbudowane narzędzia ułatwiające komunikację w grze online Metin 2. Na dole czat ogólny - do wszystkich uczestników gry. Po lewej notatki gildii (zorganizowanych grup graczy). U góry, po prawej stronie tak zwany szept - okno czatu umożliwiające komunikację między dwoma konkretnymi graczami. W prawym dolnym rogu lista znajomych

Źródło: opracowanie własne. 


\section{Cechy charakterystyczne hipertekstu gier komputerowych}

Z powyższej analizy wynika, że gry komputerowe mogą być postrzegane jako hiperteksty, gdyż mają ich charakterystyczną strukturę i wykazują wspomniane kryteria obligatoryjne oraz w wielu przypadkach cechy fakultatywne. Cechuje je w znacznym stopniu podobieństwo do hipertekstów w sieci WWW. W grach komputerowych, w porównaniu do innych hipertekstów, można jednak zaobserwować wiele cech specyficznych.

Przede wszystkim jest to pewna zależność w strukturze międzywęzłowej świata gry, którą można określić jako globalną linearność. Hipertekstualny świat gry komputerowej, jak już wspomniano, jest zbudowany nielinearnie, gdyż nie ma z góry ustalonej kolejności aktywacji linków. Gry PC, w szczególności gry offline, mają jednak w wielu przypadkach z góry narzucony początek i koniec. Za początek można uznać menu główne, gdyż tylko z tego miejsca można zostać odesłanym do węzła świata gry. Koniec lub jego różne warianty znajdują się natomiast w miejscu zakończenia fabuły - mogą to być na przykład napisy końcowe. Taki układ fabuły powoduje, że istnieją połączenia między węzłami czy też linki, które muszą zostać aktywowane, aby odblokować dostęp do kolejnych nielinearnie zorganizowanych węzłów, prowadzących w końcu do zakończenia akcji gry. Najprościej da się to zobrazować graficznie na przykładzie struktury gry Gothic (rys. 9).

\section{Gra Gothic}

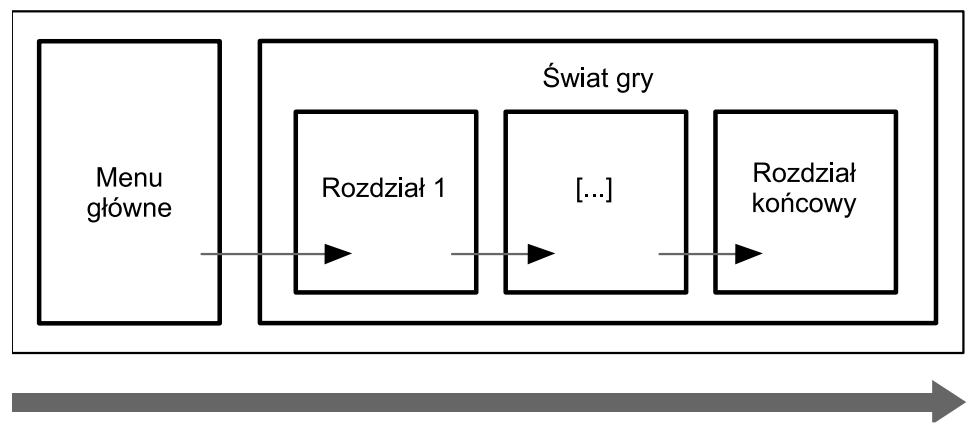

Rysunek 9. Przedstawienie graficzne globalnej linearności na przykładzie struktury gry PC Gothic

Źródło: opracowanie własne.

Gra ta podzielona jest na kilka rozdziałów. Zaczyna się, jak już zostało wcześniej ustalone, w menu głównym, gdzie można aktywować link do pierwszego rozdziału gry właściwej, czyli świata gry. Wszystkie rozdziały mają strukturę nielinearną, gdyż składają się z wielu węzłów oraz linków, do których gracz ma dostęp bez narzucenia jakiejkolwiek kolejności. Aby przejść do węzła początkowego kolejnego rozdziału, należy jednak aktywować jeden konkretny lub ewentualnie kilka wybranych linków. Ponadto nie można pominąć któregokolwiek rozdziału, są one zatem ułożone linearnie. Gra Gothic jest więc strukturą hipertekstualną złożoną z wielu linearnie połączonych rozdziałów, które jednak składają się z nieskończenie wielu nielinearnie zorganizowanych węzłów. 


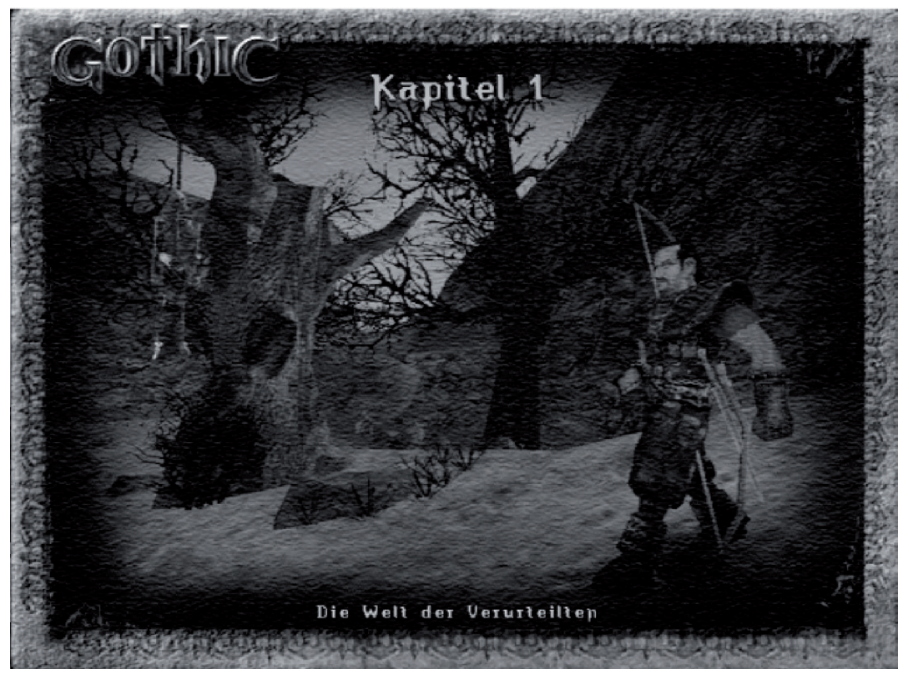

Rysunek 10. Węzeł łączący rozdziały w grze offline Gothic. Na dole tytuł rozdziału, u góry jego numer, w lewym górnym rogu nazwa gry. W centrum obraz statyczny zdobiący węzeł oraz po części wizualizujący możliwą kontynuację posunięć recepcyjnych w obrębie hipertekstu Źródło: opracowanie własne.

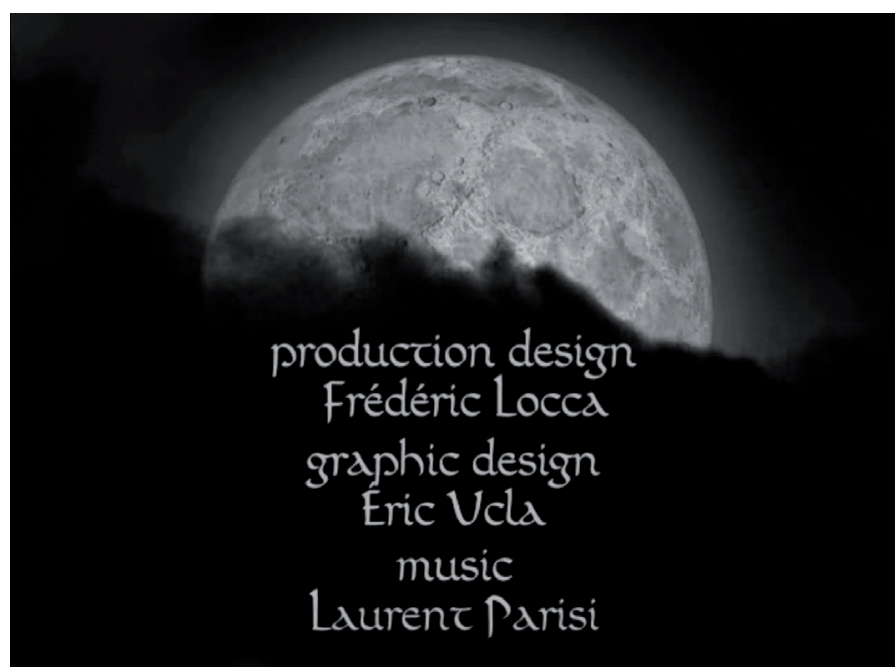

Rysunek 11. Przykładowy węzeł końcowy w grze Necronomicon: Świt Ciemności - napisy końcowe

Źródło: opracowanie własne.

Kolejną cechą specyficzną dla gier komputerowych jest możliwość ustalenia granic struktury hipertekstu. Można zatem mówić o pewnego rodzaju obecności granic formalnych. W sieci WWW granice hipertekstu mogą być ustalone tylko wtedy, gdy weźmie 
się pod uwagę temat hipertekstu lub ewentualnie jego layout. Hipertekst sieci WWW kończy się wówczas, gdy zaczyna się kolejny temat. Nie istnieją granice formalne, a granice tematyczne są zasadniczo bardzo płynne i można się sprzeczać o konkretne miejsce ich położenia. Warto zaznaczyć, że hiperteksty sieci WWW odtwarzane są przez różnego rodzaju software. W przypadku gier PC hipertekst jest sam w sobie pewnym software'em. Można zatem ustalić konkretne granice hipertekstu, jakimi są granice tego właśnie software’u. Nie można jednak wykluczyć, że gra PC składa się nie z jednego, lecz kilku hipertekstów lub hipertekstów oraz e-tekstów. Granice między nimi należałoby wtedy ustalać wyłącznie tematycznie.

Jako następną cechę wyjątkową hipertekstualnych gier PC można wymienić ich przestrzenność. Rozumiany jest przez to sposób rozłożenia linków w węzłach świata gry. Dostęp do linków często nie jest bowiem uzyskiwany poprzez zwykłe ruchy kursorem myszy, kliknięcia czy też scrolling. Odbiorca hipertekstu jest natomiast zmuszony do wirtualnej ,podróży” w często trójwymiarowym węźle świata gry, aby dotrzeć do linku, jakim może być przykładowo jakaś konkretna postać sterowana przez komputer lub miejsce w świecie gry. Warto także zaznaczyć, że położenie linków w przypadku postaci jest często zmieniane na bieżąco, gdyż mogą się one przemieszczać w węźle świata gry.

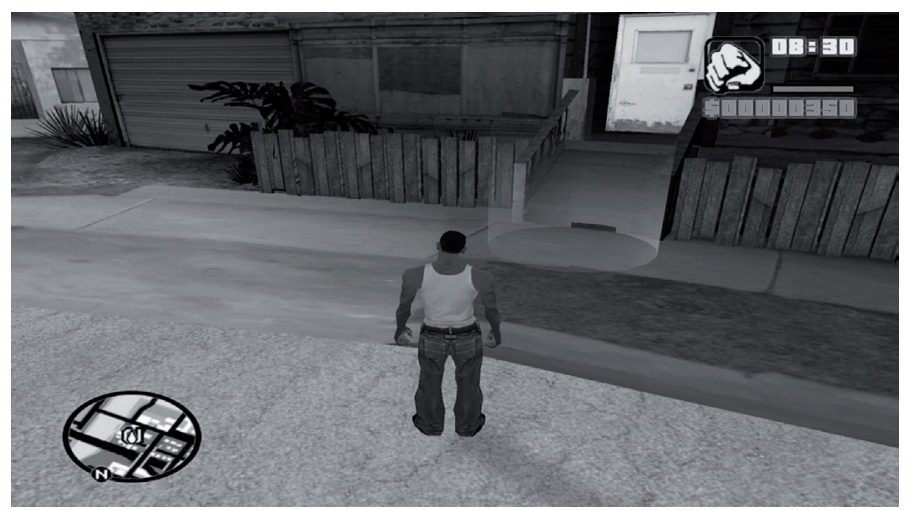

Rysunek 12. Przykład przestrzenności węzła świata gry w grze Grand Theft Auto: San Andreas. Czerwony znacznik stanowi link w wirtualnej, trójwymiarowej przestrzeni węzła świata gry, który może zostać aktywowany wyłącznie poprzez ustawienie postaci w tym znaczniku Źródło: opracowanie własne.

\section{Podsumowanie}

Gry komputerowe mogą być odbierane jako pewnego rodzaju hiperteksty. Są one skomputeryzowane i co za tym idzie - w dużym stopniu zautomatyzowane, a ich struktura wykazuje złożoną nielinearność. W przypadku cech fakultatywnych można jednak zaobserwować różnice między tradycyjną hipertekstowością elementów sieci WWW a hipertekstualnością gier komputerowych. Niektóre z nich stają się w przypadku gier kryteriami zdecydowanie obowiązkowymi, na przykład multikodalność i interakcja, 
inne są obligatoryjne jedynie dla wybranych rodzajów gier, na przykład dynamika oraz wspieranie komunikacji w przypadku gier online. Niektóre cechy fakultatywne zanikają w określonych rodzajach gier całkowicie, jest to przykładowo brak możliwości komunikacji z innymi odbiorcami w grach offline. Ponadto gry PC wykazują dodatkowe cechy specyficzne, niewystępujące lub występujące bardzo rzadko w hipertekstach sieci WWW.

\section{Bibliografia}

Ackermann J. (2011), Gemeinschaftliches Computerspielen aufLAN-Partys: Kommunikation, Medienaneignung, Gruppendynamiken, Berlin.

Charles D., Fyfe C., Livingstone D., McGlinchey S. (2007), Biologically Inspired Artificial Intelligence for Computer Games, Hershey-New York.

Fritz J. (1988), Videospiele zwischen Faszination, Technik und Kommerz, [w:] J. Fritz (red.), Programmiert zum Kriegspielen: Weltbilder und Bilderwelten im Videospiel, Bonn.

Huber O. (2003), Hyper-Text-Linguistik: TAH: Ein textlinguistisches Analysemodell für Hypertexte, Monachium.

Jacko J.F. (2016), Czym jest gra? Uwagi o przedmiocie ludologii. Analiza fenomenologiczno-metodologiczna, „Homo Ludens”, nr 9.

Klimmt C. (2001), Ego-Shooter, Prügelspiel, Sportsimulation? Zur Typologisierung von Computer- und Videospielen, „Medien \& Kommunikationswissenschaft”, nr 49.

Nelson T.H. (1972), As We Will Think, [w:] J.M. Nyce, P. Kahn (red.), From Memex to Hypertext: Vannevar Bush and the mind's machine, Boston.

Nelson T.H. (1965), Complex information processing: A file structure for the complex, the changing and the indeterminate, [w:] L. Winner (red.), Proceedings of the 1965 20th national conference, Nowy Jork.

Posner R. (1986), Zur Systematik der Beschreibung verbaler und non-verbaler Kommunikation, [w:] H.G. Bosshardt, Perspektiven auf Sprache: Interdisziplinäre Beiträge zum Gedenken an Hans Hörmann, Berlin.

Posner R. (1991), Kultur als Zeichensystem. Zur semiotischen Explikation kulturwissenschaftlicher Grundbegriffe, [w:] A. Assmann, D. Harth (red.), Kultur als Lebenswelt und Monument, Frankfurt nad Menem.

Schmitz U. (2015), Einführung in die Medienlinguistik, Darmstadt.

Stertkamp W. (2017), Sprache und Kommunikation in Online-Computerspielen. Untersuchungen zu multimodaler Kommunikation am Beispiel von World of Warcraft, Gießen.

Storrer A. (2008), Hypertextlinguistik, [w:] N. Janich (red.), Textlinguistik: 15 Einführungen, Tybinga.

Walz S.P. (2010), Toward a Ludic Architecture: The Space of Play and Games, Pittsburgh.

\section{Publikacje internetowe}

Miejsce gier w kulturze i społeczeństwie (2012), http://www.naukaipostep.pl/wiadomosci/ miejsce-gier-w-kulturze-i-spoleczenstwie/ [dostęp: 20.10.2021]. 


\section{Abstract \\ Computer games as hypertexts}

The article deals with the media-linguistic analysis of selected computer games, in particular focusing on the category of hypertextuality. Different types of computer games are analyzed, with the aim of demonstrating their media-conditioned heterogeneity. It will be examined whether they meet the criteria of hypertextuality and, if so, whether it is full or partial hypertextuality, i.e., whether a computer game is one hypertext as a whole or whether it is a creation composed of one or more hypertexts and possibly other elements. Within the scope of the analysis, it will also be verified whether computer games have specific features that distinguish them from the most popular form of hypertext - namely, from texts that are part of the WWW.

Keywords: mediality, hypertext, computer game, textuality 